\title{
SISTEM PENGAMBILAN KEPUTUSAN UNTUK PEMILIHAN BIDANG KEAHLIAN BAGI MAHASISWA TEKNIK ELEKTRO UNIVERSITAS MATARAM MENGGUNAKAN LOGIKA FUZZY MAMDANI BERTINGKAT
}

\author{
Decision Making System for Determining Student Expertise Area in \\ Electrical Engineering University of Mataram Using Graded Mamdani Fuzzy \\ Logic
}

\author{
Yusron Rizki Ardiansyah ${ }^{[1]}$, Misbahuddin ${ }^{[1]}$, Lalu A. Syamsul Irfan Akbar ${ }^{[1]}$ \\ ${ }^{[1]} J u r u s a n$ Teknik Eelektro, Universitas Mataram \\ Jl. Majapahit 62, Mataram, Lombok NTB, INDONESIA \\ Email:yusronr24@gmail.com
}

\begin{abstract}
ABSTRAK
Jurusan Teknik Elektro Universitas Mataram menerapkan kurikulum yang mewajibkan mahasiswa memilih bidang keahlian setelah semester empat berdasarkan Indeks Prestasi Kumulatif (IPK). Hal ini membuat mahasiswa yang memiliki nilai rendah akan sulit untuk mendapatkan bidang keahlian penjurusan yang memiliki peminatan paling banyak dan tidak memiliki rekomendasi lain dari hasil pembagian bidang keahlian tersebut. Oleh karena itu, penelitian ini bertujuan untuk menerapkan sistem pengambilan keputusan untuk setiap peminatan bidang keahlian. Parameter yang digunakan sebagai data masukan dalam penentuan bidang keahlian adalah nilai mata kuliah dasar, IPK, minat mahasiswa, keinginan orang tua, dan keterampilan mahasiswa dalam menentukan peminatan bidang keahlian sebagai pengembangan dari sistem sebelumnya. Metode yang digunakan untuk mengola data masukan adalah logika Fuzzy Inferense System (FIS) dengan pendekatan fuzzy Mamdani bertingkat yang terdiri dari tahapan: fuzzifikasi, implikasi, komposisi aturan, dan defuzzifikasi. Jumlah sampel data yang digunakan sebanyak 65 data mahasiswa dari empat bidang keahlian. Hasil pengujian menunjukkan bahwa tingkat akurasi dari perbandingan antara hasil penentuan bidang keahlian dari sistem fuzzy Mamdani dan faktanya adalah sebesar $80 \%$. Pengukuran kepuasaan pengguna sebesar $87.62 \%$ dari 21 responden. Sistem pendukung keputusan ini dapat mempermudah mahasiswa dan pengelola Jurusan Teknik Elektro Universitas Mataram dalam mengelola dan menganalisis penentuan bidang keahlian.
\end{abstract}

Kata Kunci: Sistem Pengambilan Keputusan, Fuzzy Inference System, Fuzzy Mamdani Bertingkat

\begin{abstract}
The Department of Electrical Engineering at Mataram University implements a curriculum that requires the students to choose a specialization based on their Grade Point Average (GPA) after semester four. Sometimes, this could be difficult for the students with low GPA to majoring the specialization with the most participants and has no other recommendations to choose the specialization. Therefore, this study aims to apply a decision-making system for any area of expertise. The input parameters in this study are the course scores, GPA scores, student's interests, parents' desires, and student's skills as a development of the previous system. The input data was processed using the fuzzy Mamdani method with several stages, namely fuzzification, implication, the composition of rules, and defuzzification. The number of data samples is 65 from four concentrations. The comparison of the accuracy between the results of the concentration determined in the Department of Electrical Engineering and the results of the fuzzy Mamdani system in stages using 65 student data by $80 \%$. The measurement of the user satisfaction for the eligibility of the system is $87.62 \%$ for a total of 21 respondents. This decision-making system can help easily the Department of Electrical Engineering at Universitas Mataram in processing and analyzing student data in helping to choose a specialization.
\end{abstract}

Keywords: Decision Making System, Fuzzy Inference System, Graded Fuzzy Mamdani 


\section{PENDAHULUAN}

Program Studi adalah kesatuan rencana belajar sebagai pedoman Penyelenggaraan pendidikan akademik dan/ atau profesional yang diselenggarakan atas dasar suatu kurikulum yang ditujukan agar mahasiswa dapat menguasai pengetahuan, keterampilan, dan sikap yang sesuai dengan sasaran kurikulum. (Mendikbud No. 036/U/1993, pasal 1, ayat (6)). Pada suatu program studi mahasiswa dituntut untuk mengeluarkan seluruh kemampuan, bakat dan potensi dari diri mereka sesuai jalur yang telah diambilnya tersebut. Namun pada kenyataannya terdapat sebagian mahasiswa yang belum bisa memutuskan untuk fokus pada keahlian tertentu.

Jurusan Teknik Elektro Universitas Mataram pada akhir semester ke IV diwajibkan untuk memilih salah satu bidang keahlian yaitu, Sistem Tenaga Listrik, Elektronika digital, Teknik Komputer, dan Telekomunikasi. Pemilihan bidang keahlian di Jurusan Teknik Elektro menggunakan nilai Indeks Prestasi Kumulatif (IPK) dari semester 1 sampai semester 4, serta beberapa mata kuliah dasar yang dihitung secara manual dan diurutkan sesuai bidang keahlian yang dipilih mahasiswa. Penentuan bidang keahlian secara manual ini tentu memiliki berbagai kekurangan misalnya tidak ada opsi ke dua untuk mahasiswa jika tidak bias masuk pada bidang keahlian yang diminatinya.

Beberapa peneliti telah melakukan penelitian tentang sistem pendukung keputusan dalam menentukan peminatan mahasiswa, diantaranya (Yulmaini, 2011) menggunakan Fuzzy Inference system (FIS) metode Tsukamoto sebagai pemilihan peminatan mahasiswa untuk Tugas Akhir. Pada penelitian tersebut tidak mempertimbangkan minat dan bakat mahasiswa. Hal serupa juga diteliti oleh (Vinsensia dkk, 2018) menggunakan Fuzzy Inference system (FIS) metode Mamdani untuk pemilihan jurusan perguruan tinggi. Namun pada penelitian tersebut tidak mempertimbangkan hasil peminatan lainnya dalam menentukan jurusan.
Berdasarkan pemaparan di atas maka perlu dilakukan pengembangan sebuah sistem pengambilan keputusan untuk setiap peminatan bidang keahlian, menggunakan logika fuzzy metode Mamdani secara bertingkat berbasis web karena Metode Fuzzy Mamdani dalam proses penarikan hasilnya menggunakan kaedah-kaedah linguistik dan memiliki algoritma fuzzy yang dapat dianalisis secara matematika, sehingga lebih mudah dipahami.. Sistem tersebut diharapkan mampu menjadi fasilitas pendukung dalam penentuan bidang keahlian yang sesuai dengan kemampuan, minat dan keterampilan untuk mahasiswa Teknik Elektro Universitas Mataram.

\section{A. Logika fuzzy}

Logika Fuzzy adalah peningkatan dari logika Boolean yang mengenalkan konsep kebenaran sebagian. Di mana logika klasik menyatakan bahwa segala hal dapat diekspresikan dalam istilah binary ( 0 atau 1 , hitam atau putih, ya atau tidak), logika fuzzy menggantikan kebenaran boolean dengan tingkat kebenaran (Ratama \& Munawaroh, 2019). Pada logika fuzzy dikenal dengan konsep kebenaran sebagian yang berarti keputusan atau hasil dari logika fuzzy tidak dapat dikatakan benar 100\%, logika fuzzy menggantikan istilah kebenaran sebagian tersebut dengan istilah linguistik seperti "sedikit", "lumayan", dan "sangat" (Ratama \& Munawaroh, 2019). Logika fuzzy memiliki derajat keanggotaan yang bernilai antara nol (0) sampai satu (1).

\section{B. Fuzzy Inference system (FIS)}

Fuzzy Inference system adalah sebuah kerangka kerja perhitungan berdasarkan konsep teori himpunan fuzzy dan pemikiran fuzzy yang digunakan dalam penarikan kesimpulan atau suatu keputusan (Kusumadewi, 2006). Penarikan kesimpulan dilakukan berdasarkan sekumpulan kaidah fuzzy, di dalam Fuzzy Inference system terdapat dua buah kaidah fuzzy. Fuzzy Inference system terbagi menjadi dua metode, yaitu Metode Sugeno dan Metode Fuzzy Mamdani.

Perbedaan dari kedua metode ini terletak pada output yang dihasilkan, proses komposisi aturan dan 
defuzzifikasi-nya. Pada Metode Sugeno, output yang dihasilkan berupa fungsi linear atau konstanta. Sedangkan Output dari Metode Fuzzy Mamdani berbeda dengan hasil tersebut, dimana metode ini menghasilkan output berupa suatu nilai pada domain himpunan fuzzy yang dikategorikan ke dalam komponen linguistik.

\section{Metode fuzzy Mamdani}

Metode Fuzzy Mamdani merupakan salah satu bagian dari Fuzzy Inference system yang digunakan sebagai penarikan kesimpulan atau suatu keputusan terbaik dalam memecahkan permasalahan yang tidak pasti (Bova et al., 2010). Metode Fuzzy Mamdani diperkenalkan oleh Ebrahim Mamdani pada tahun 1975. Metode Fuzzy Mamdani dalam prosesnya penarikan hasilnya menggunakan kaedah-kaedah linguistik dan memiliki algoritma fuzzy yang dapat dianalisis secara matematika, sehingga lebih mudah dipahami.

\section{Perancangan Sistem}

Pada metode Fuzzy Mamdani terdapat beberapa langkah untuk menentukan Bidang Keahlian (KBK) pada Jurusan Teknik Elektro Universitas Mataram, berikut diagram alir untuk menentukan bidang keahlian tersebut.

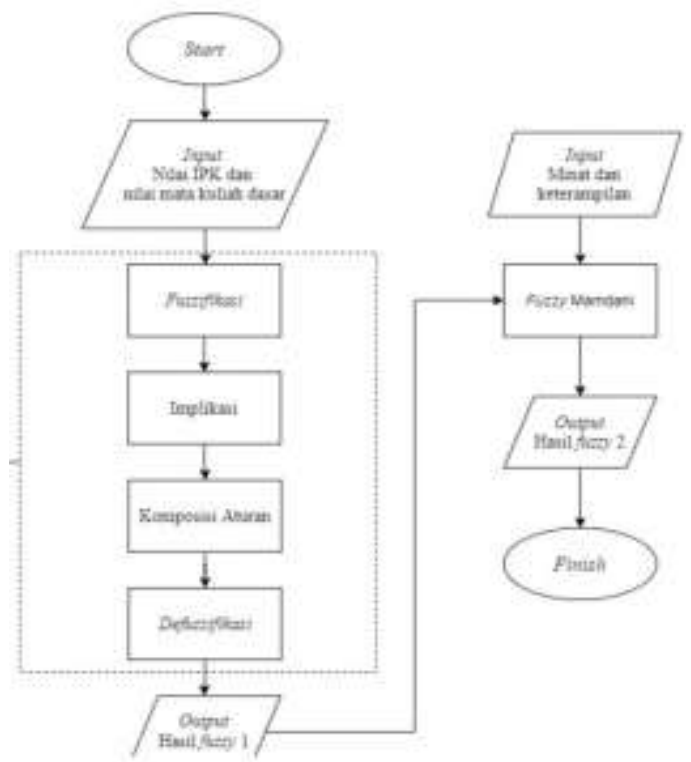

Gambar 1. Diagram alir FIS Mamdani

\section{E. Analisis Kebutuhan}

Pada penelitian ini digunakan beberapa kebutuhan yang menunjang pelaksanaan penelitian sebagai berikut:

1. Nilai IPK

2. Nilai Mata Kuliah Dasar bidang keahlian Sistem Tenaga Listrik :

- Nilai Rangkaian Listrik I

- Nilai Dasar Tenaga Listrik

3. Nilai Mata Kuliah Dasar bidang keahlian Teknik Komputer :

- Nilai Algoritma Pemrograman

- Nilai Dasar Teknologi Informasi

4. Nilai Mata Kuliah Dasar bidang keahlian Elektronika:

- Nilai Dasar Elektronika

- Nilai Rangkaian Logika

5. Nilai Mata Kuliah Dasar bidang keahlian Telekomunikasi :

- Nilai Dasar Telekomunikasi

- Nilai Probabilitas dan Statistik

6. Minat dan keterampilan mahasiswa

Minat dan keterampilan mahasiswa didapatkan berdasarkan angket yang diisi oleh mahasiswa serta orang tua dari mahasiswa tersebut. Sedangkan keterampilan mahasiswa didapatkan dari sertifikat atau piagam atau dokumen valid dari mahasiswa yang sesuai dengan bidang keahlian yang tersedia.

\section{F. Prosedur metode Mamdani}

Metode Mamdani dikenal juga sebagai Metode Max-Min. Metode ini diperkenalkan oleh Ebrahim Mamdani pada tahun 1975. Untuk mendapatkan output, diperlukan 4 tahapan :

\section{F.1 Pembentukan Himpunan Fuzzy (Fuzzifikasi)}

Logika fuzzy metode Mamdani terdapat beberapa pemetaan untuk variabel input himpunan fuzzy. Fungsi keanggotaan digunakan untuk menghitung derajat keanggotaan suatu himpunan fuzzy. Berikut beberapa grafik fungsi keanggotaan yang akan digunakan pada penelitian ini. 
- Nilai IPK

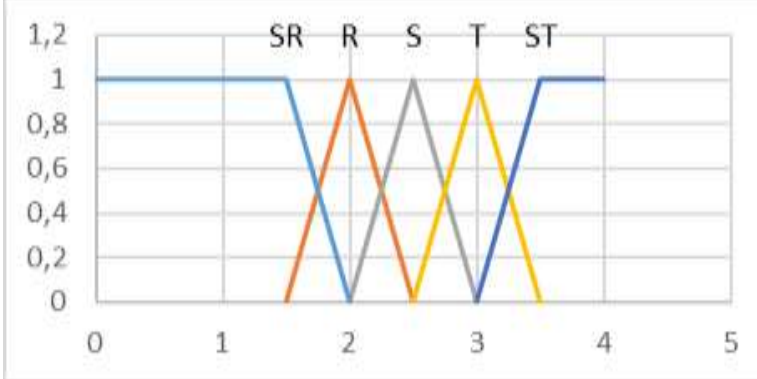

Gambar 2. Fungsi keanggotaan nilai IPK

Fungsi keanggotaan :

$\mu$ IPKSangatRendah $[\mathrm{X}]=\left\{\begin{array}{c}1, x \leq 1,5 \\ \frac{2-x}{2-1,5}, 1,5<x<2 \ldots . \\ 0, x \geq 2\end{array}\right.$

(1)

$\mu \mathrm{IPKRendah}[\mathrm{x}]=\left\{\begin{array}{l}0, x \leq 1,5 \text { atau } x \geq 2,5 \\ \frac{x-1,5}{2-1,5}, 1,5<x<2 \\ \frac{2,5-x}{2,5-2}, 2<x<2,5\end{array}\right.$

$\mu \mathrm{IPKSedang}[\mathrm{X}]=\left\{\begin{array}{l}0, x \leq 2 \operatorname{ataux} \geq 3 \\ \frac{x-2}{2,5-2}, 2<x<2,5 \\ \frac{a-x}{\mathrm{a}-2,5}, 2,5<x<3\end{array}\right.$.

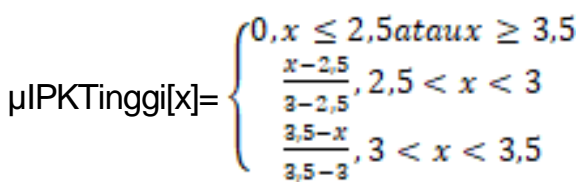

$\mu$ IPKSangatTinggi $[\mathrm{x}]=\left\{\begin{array}{c}0, x \leq 3 \\ \frac{x-\mathrm{a}}{\mathrm{a}, 5-\mathrm{a}}, 3<x<3,5 \\ 1, x \geq 3,5\end{array}\right.$

- Nilai Mata Kuliah Dasar

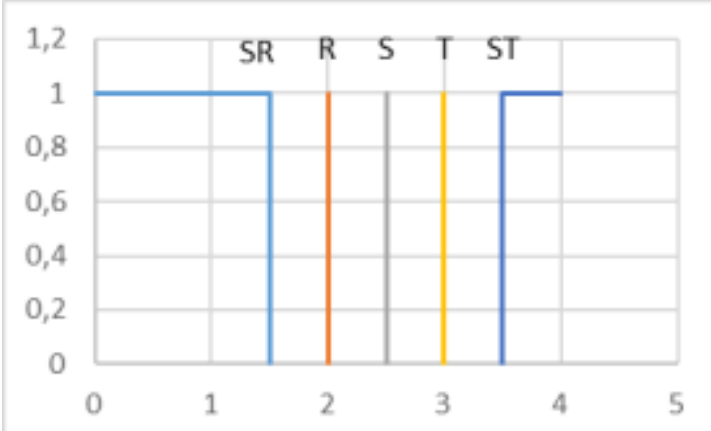

Gambar 3. Fungsi keanggotaan nilai Mata Kuliah

Dasar

Fungsi keanggotaan : $\mu$ MKSangatRendah $[\mathrm{x}]=\left\{\begin{array}{l}1, x \leq 1,5 \\ 0, x>1,5\end{array}\right.$

$\mu$ MKRendah $[\mathrm{x}]=\left[\begin{array}{c}0, x<2 \text { ataux }>2 \\ 1, x=2\end{array}\right.$

$\mu \mathrm{MKSedang}[\mathrm{x}]=\left\{\begin{array}{c}0, x<2,5 \text { atoux }>2,5 \\ 1, x=2,5\end{array}\right.$

$\mu \mathrm{MKTinggi}[\mathrm{x}]=\left\{\begin{array}{c}0, x<3 \operatorname{atau} x>3 \\ 1, x=3\end{array}\right.$

$\mu$ MKSangatTinggi $[\mathrm{x}]=\left\{\begin{array}{l}1, x \geq 3,5 \\ 0, x<3,5\end{array}\right.$

- Hasil fuzzy 1

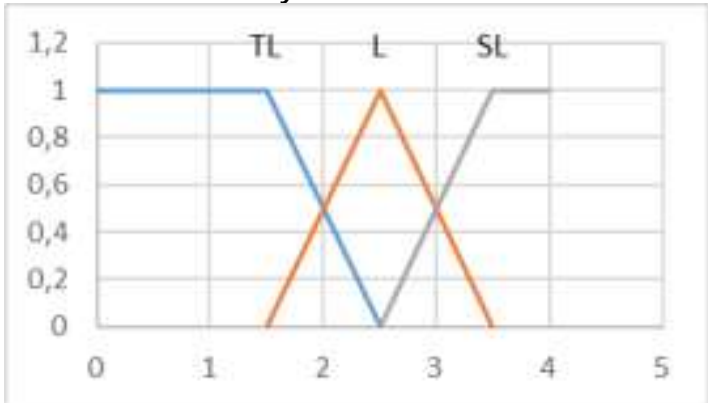

Gambar 4. Fungsi keanggotaan hasil fuzzy 1

Fungsi keanggotaan :

$\mu$ HasilfuzzyTidaklayak $[x]=$

$\left\{\begin{array}{c}1, x \leq 1,5 \\ \frac{2,5-x}{2,5-1,5}, 1,5<x<2,5 \\ 0, x \geq 2,5\end{array}\right.$

$\mu$ HasilfuzzyLayak $[\mathrm{x}]=\left\{\begin{array}{l}0, x \leq 1,5 \text { ataux } \geq 3,5 \\ \frac{x-1,5}{2,5-1,5}, 1,5<x<2,5 \\ \frac{a, 5-x}{2,5-2,5}, 2,5<x<3,5\end{array}\right.$

$\mu$ HasilfuzzySangatlayak $[x]=$

$\left\{\begin{array}{c}1, x \geq 2,5 \\ \frac{x-2,5}{2,5-2,5}, 2,5<x<3,5 \\ 0, x \leq 3,5\end{array}\right.$ 
- Minat dan keterampilan

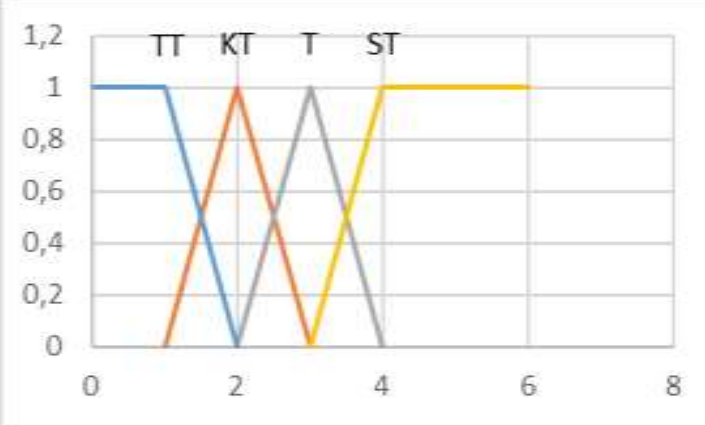

Gambar 5. Fungsi keanggotaan minat dan keterampilan

Fungsi keanggotaan :

$\mu$ MinatTidakTertarik $[\mathrm{x}]=\left\{\begin{array}{c}1, x \leq 1 \\ \frac{2-x}{2-1}, 1<x<2 \ldots \\ 0, x \geq 2\end{array}\right.$

$\mu$ MinatKurangTertarik $[\mathrm{x}]=\left\{\begin{array}{c}0, x \leq 1 \text { ataux } \geq 3 \\ \frac{x-1}{2-1}, 1<x<2 \\ \frac{a-x}{a-2}, 2<x<3\end{array}\right.$

$\mu$ MinatTertarik $[\mathrm{x}]=\left\{\begin{array}{l}0, x \leq 2 \operatorname{ataux} \geq 4 \\ \frac{x-2}{a-2}, 2<x<3 \\ \frac{a-x}{2-4}, 3<x<4\end{array}\right.$

$\mu$ MinatSangatTertarik $[\mathrm{x}]=\left\{\begin{array}{c}0, x \leq 3 \\ \frac{x-a}{4-a}, 3<x<4(17) \\ 1, x \geq 4\end{array}\right.$

Pada minat mahasiswa terbagi menjadi 4 prioritas pilihan bidang keahlian yang memiliki bobot berdasarkan $70 \%$ dari minat mahasiswa dan $30 \%$ dari pilihan orang tua. Sedangkan pada keterampilan mahasiswa diperoleh berdasarkan sertifikat mengikuti pelatihan/event yang sesuai biang keahlian dengan bobot sebesar 0,3 , sertifikat mengikuti lomba sesuai bidang keahlian dengan bobot sebesar 0,4 dan sertifikat atau dokumen kerja sesuai bidang keahlian dengan bobot 0,4.

\section{F.2 Fungsi Implikasi}

Tahap kedua dari prosedur Metode Fuzzy Mamdani adalah penerapan fungsi implikasi. Secara umum aturan fuzzy memiliki bentuk

$$
\operatorname{IF}\left(X_{1} \text { is } A_{1}\right) \wedge\left(X_{2} \text { is } A_{2}\right) \wedge \ldots \ldots
$$

$\left(X_{n}\right.$ is $\left._{n}\right)$ THENYisB
Banyaknya $n$ ditentukan berdasarkan jumlah dari variabel input fuzzy yang digunakan (Lahsasna et al., 2010). Suatu proposisi ini digunakan untuk pembentukan keputusan atau menghasilkan output dari proposisi yang telah ditentukan. Penentuan proposisi ini dibentuk berdasarkan kriteria-kriteria yang telah ditentukan dengan penilaian yang sesuai dengan objek, dan berdasarkan fakta yang diketahui. Setelah terbentuknya proposisi, selanjutnya adalah menentukan nilai keanggotaan berdasarkan aturan fuzzy yang telah dibentuk menggunakan fungsi implikasi Min. Pada fungsi implikasi Min, digunakan operator AND (interseksi).

$a-$ predikat $_{i}=\mu A_{1}\left[X_{1}\right] \cap \ldots \cap A_{n}\left[X_{n}\right]$

$\min$

Dimana, i adalah aturan fuzzy ke-i

Jumlah aturan yang terbentuk dari beberapa fungsi keanggotaan yang telah disusun masing-masing peminatan sebanyak 125 aturan pada tahap pertama dan 12 aturan pada tahap kedua, sehingga terdapat 548 aturan untuk seluruh bidang keahlian.

\section{F.3. Komposisi Aturan}

Pada tahap ketiga metode fuzzy Mamdani untuk menentukan komposisi aturan yang bertujuan untuk menentukan inferensi dari kumpulan dan korelasi antar aturan menggunakan Metode Max, dengan makna lain yaitu prosedur menggabungkan fungsi keanggotaan dari aturan aplikasi fungsi implikasi.

$\mu_{s f}\left(X_{i}\right)=\max \left(\mu_{s f}\left(X_{i}\right)_{s} \mu_{k f}\left(X_{i}\right)\right)$

Dengan $\mu_{s f}\left(X_{\mathrm{i}}\right)$ sebagai nilai keanggotaan solusi fuzzy sampai aturan ke-I dan $\mu_{k f}\left(X_{i}\right)$ sebagai nilai keanggotaan konsekuensi fuzzy aturan ke-i.

\section{F.4. Defuzzifikasi}

Pada tahap akhir proses fuzzy Mamdani adalah proses defuzzifikasi. Proses ini bertujuan untuk mengkonversi nilai besaran keanggotaan fuzzy menjadi nilai bilangan real yang bersifat akhir (final). Proses ini dilakukan dengan mengembalikan output dari besaran fuzzy menjadi nilai crisp (real). Pada saat menentukan titik pusat daerah fuzzy dilakukan dengan menggunakan rumus : 
$Z *=\frac{\sum_{j=1}^{n} z_{j j} p\left(z_{j}\right)}{\sum_{j=1} \mu\left(z_{j}\right)}$

Dengan $Z^{*}$ sebagai nilai hasil defuzzifikasi atau titik pusat daerah fuzzy, $\mu(z \mid j)$ sebagai derajat keanggotaan nilai keluaran pada aturan ke-j dan $\sum_{j=1}^{n} z_{j} \mu\left(z_{j}\right)$ sebagai momen untuk semua daerah hasil komposisi aturan.

\section{F.5. Hasil Akhir}

Keluaran Linguistik:

Tidak Layak $\quad:<2$

Layak $: 2 \leq Z^{*}<3$

Sangat Layak $: 3 \leq Z^{*} \leq 4$

Dari daftar luaran linguistik diatas, jika hasil dari defuzzifikasi sebesar 2,8 maka termasuk dalam termasuk dalam kategori Layak.

\section{G. Diagram Konteks}

Diagram konteks adalah diagram yang terdiri dari suatu proses dan menggambarkan ruang lingkup suatu sistem (Muslihudin \& Oktafianto, 2016). Diagram konteks sistem pendukung keputusan penentuan bidang keahlian pada Jurusan Teknik Elektro Universitas Mataram menggambarkan aliran program secara umum, dapat dilihat pada Gambar 6.

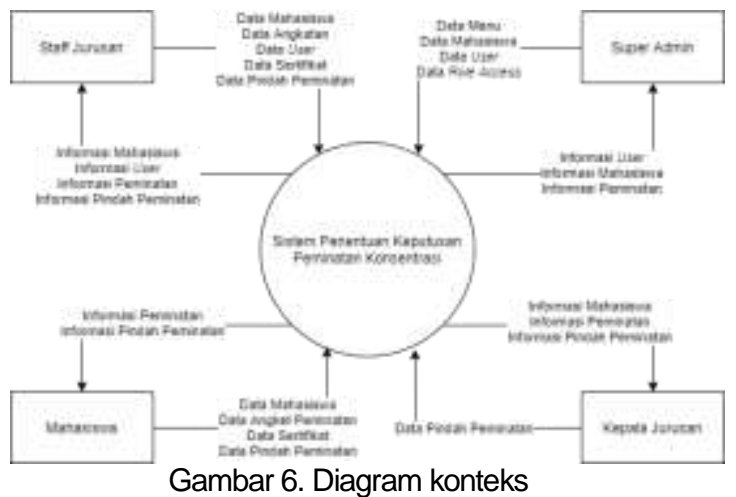

\section{H. Use Case Diagram}

Diagram use case digunakan untuk menggambarkan atau representasi dari interaksi yang terjadi antara sistem dan lingkungannya. Use case diagram memberi gambaran singkat hubungan antara use case, aktor, dan sistem. Use case diagram pada penelitian ini dapat dilihat pada Gambar 7 . sebagai berikut:

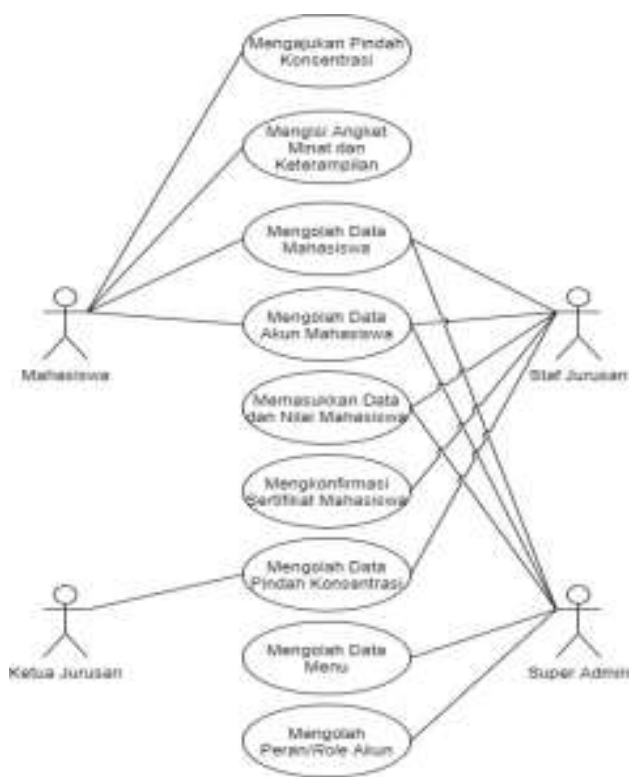

Gambar 7. Use Case Diagram

\section{Entity Relationship Diagram (ERD)}

Diagram ER biasanya berhubungan langsung dengan data flow diagram(DFD) untuk menampilkan konten data. Entity Relationship Diagram pada penelitian ini dapat dilihat pada Gambar 8. sebagai berikut:

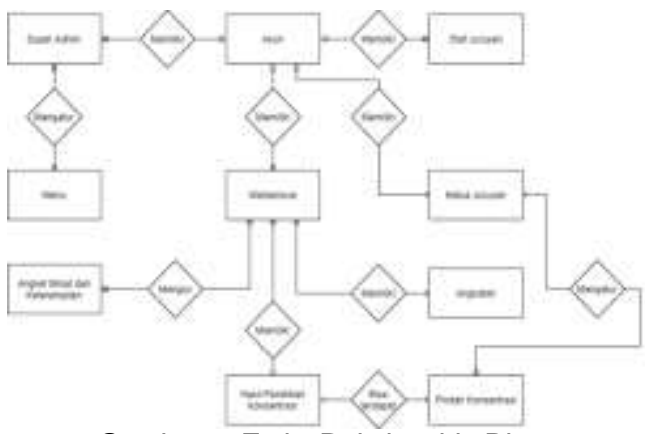

Gambar 8. Entity Relationship Diagram

\section{J. Cara Pengujian}

Pengujian dilakukan ketika sistem yang dibangun telah rampung dan penguji mengunggah sistem penentuan bidang keahlian tersebut ke hosting. Setelah sistem dapat diakses oleh semua orang melalui internet, penguji akan meminta data pribadi, nilai dan hasil pemilihan bidang keahlian mahasiswa angkatan 2018 ke Jurusan Teknik Elektro Universitas Mataram. Pada saat data yang dibutuhkan telah diolah, maka peneliti akan mengunggah data - data tersebut ke sistem dan meminta mahasiswa angkatan 2018 untuk mengisi angket minat dan keterampilan mahasiswa.

Ketika data yang dibutuhkan dianggap sudah memenuhi target, kemudian peneliti 
akan melakukan proses penentuan bidang keahlian kepada seluruh responden. Setelah mendapatkan hasil penentuan bidang keahlian berdasarkan logika fuzzy Mamdani secara bertingkat, selanjutnya peneliti akan membuat kuesioner untuk mengukur kinerja dan kualitas dari sistem yang dibangun. Pada tahapan terakhir pengujian, peneliti akan mengumumkan hasil penentuan bidang keahlian tersebut beserta mengirimkan link kuesioner yang telah dibuat.

\section{K. Pengujian Sistem}

Pengujian sistem dilakukan dengan membagikan kuesioner kepada 21 responden untuk mengukur kinerja dan kualitas dari sistem yang dibangun seperti yang terlihat pada Tabel 1.

Tabel 1. Hasil Kuesioner pengujian sistem

\begin{tabular}{|c|c|c|c|c|c|c|c|c|}
\hline \multirow{2}{*}{ No } & \multirow{2}{*}{ Pertanyaan } & \multicolumn{5}{|c|}{ Skor } & \multirow{2}{*}{$\begin{array}{l}\text { Jumlah } \\
\text { skor }\end{array}$} & \multirow{2}{*}{$\begin{array}{c}\text { Persentase } \\
\text { Jawaban } \\
(\%)\end{array}$} \\
\hline & & 1 & 2 & 3 & 4 & 5 & & \\
\hline 1 & $\begin{array}{l}\text { Apakah website tersebut } \\
\text { mudah disumakan? }\end{array}$ & & & 4 & 7 & 10 & 90 & 85,71 \\
\hline 2 & $\begin{array}{l}\text { Apakah tampilan } \\
\text { website tersebut menardk } \\
2\end{array}$ & & & 4 & 7 & 10 & 90 & 85,71 \\
\hline 3 & $\begin{array}{l}\text { Apakah website tersebut } \\
\text { berjalan balk? }\end{array}$ & & & 2 & 9 & 10 & 92 & 87,62 \\
\hline 4 & $\begin{array}{l}\text { Apakah menu pada } \\
\text { website tersebut } \\
\text { memberikan layanan } \\
\text { yang baik? }\end{array}$ & & & 3 & 11 & 7 & 88 & 83,81 \\
\hline 5 & $\begin{array}{l}\text { Apakah informasi pada } \\
\text { website tersebut sudah } \\
\text { lengkan? }\end{array}$ & & & 5 & 10 & 6 & 85 & 80,95 \\
\hline 6 & $\begin{array}{l}\text { Apakah website yang } \\
\text { dibangun tersebut } \\
\text { bermanfaat? }\end{array}$ & & & 2 & 6 & 13 & 95 & 90,48 \\
\hline 7 & $\begin{array}{l}\text { Apakah website tersebut } \\
\text { layak digunakan sebagai } \\
\text { sistem pemilihan } \\
\text { konsentrasi? }\end{array}$ & & & 2 & 9 & 10 & 92 & 87,62 \\
\hline
\end{tabular}

Dari Tabel 1 dapat diketahui bahwa berdasarkan kuesioner yang telah diberikan kepada 21 responden, menunjukkan bahwa dari tiap pertanyaan menghasilkan persentase diatas $80 \%$ dan sebesar $87.62 \%$ untuk pertanyaan website layak digunakan sebagai sistem pemilihan bidang keahlian, sehingga dari hasil tersebut dapat dikatakan sistem ini sudah mencapai hasil kualitas dan kinerja yang baik dari sisi pengguna.

\section{Hasil Penentuan sistem fuzzy dalam penentuan bidang keahlian}

Pengujian sistem dilakukan kepada 65 mahasiswa Teknik Elektro angkatan 2018 dengan hasil penentuan bidang keahlian sebanyak 14 mahasiswa pada bidang keahlian Sistem Tenaga Listrik, 23 mahasiswa pada bidang keahlian Teknik Komputer, 16 mahasiswa pada bidang keahlian Elektronika dan 12 mahasiswa pada bidang keahlian Telekomunikasi.

\section{Perbandingan Hasil Penentuan bidang keahlian Jurusan Teknik Elektro dengan Logika Fuzzy Mamdani}

Perbandingan hasil penentuan bidang keahlian pada jurusan Teknik Elektro Universitas Mataram dengan hasil dari sistem penentuan bidang keahlian menggunakan logika fuzzy Mamdani menghaislkan 13 data responden yang memiliki hasil berbeda dari 65 total responden. Perbandingan tersebut dilakukan dengan menghitung persentase tingkat akurasi sistem, digunakan rumus seperti berikut:

$$
\begin{aligned}
& \text { \%Akurasi }=\frac{\text { jumlahdatakhurat }}{\text { totalresponden }} x 100 \\
& \text { \%Akurasi }=\frac{52}{65} x 100=80 \%
\end{aligned}
$$

Dari hasil \% akurasi yang didapatkan sebesar $80 \%$, hal ini dikarenakan adanya perbedaan hasil antara sistem penentuan bidang keahlian Jurusan Teknik Elektro dengan sistem penentuan menggunakan logika fuzzy Mamdani dengan selisih perbedaan hasil sebesar 13 data mahasiswa responden. Perbedaan hasil ini dikarenakan beberapa faktor yaitu perbedaan pengolahan data pada sistem jurusan yang menghitung nilai mahasiswa pada pilihan prioritas pertama saja, penyesuaian kapasitas bidang keahlian yang telah ditentukan oleh jurusan Teknik Elektro dan permintaan dari mahasiswa yang merasa tidak sesuai dengan hasil bidang keahlian yang didapatkannya.

\section{N. Uji Recall dan Precision}

Nilai recall merupakan proporsi dokumen relevan yang terambil oleh sistem, sedangkan nilai precision adalah proporsi dokumen yang terambil oleh sistem adalah relevan (Salton, 1989). Nilai recall dan precision bernilai antara 0 sampai dengan 1. Tujuan uji Recall dan Precision adalah untuk mendapatkan informasi hasil kesesuaian antara pilihan utama (prioritas 1) mahasiswa terhadap konsentrasi dengan hasil penentuan konsentrasi menggunakan logika fuzzy Mamdani. Precision dapat dianggap sebagai ukuran ketepatan atau ketelitian, sedangkan recall adalah kesempurnaan. Semakin banyak data hasil logika fuzzy dan data pilihan utama mahasiswa maka akan semakin tinggi pula nilai recall dan 
precision sehingga diharapkan untuk dapat memberikan nilai recall dan precision mendekati 1.

Tabel 2. Data uji recall dan precision

\begin{tabular}{|c|c|c|c|}
\hline \multirow{2}{*}{$\begin{array}{c}\text { Konsentrasi } \\
\text { Jurusan }\end{array}$} & \multicolumn{3}{|c|}{ Hasil } \\
\cline { 2 - 4 } & Hits & Noise & Miss \\
\hline $\begin{array}{c}\text { Sistem Tenaga } \\
\text { Listrik }\end{array}$ & 12 & 2 & 1 \\
\hline Teknik Komputer & 19 & 3 & 4 \\
\hline Elektronika & 13 & 8 & 3 \\
\hline Telekomunikasi & 7 & 1 & 5 \\
\hline
\end{tabular}

Hits: Jumlah hasil yang sesuai antara sistem menggunakan Fuzzy Inference System dengan pilihan utama (prioritas 1) mahasiswa.

Noise: Jumlah hasil pilihan utama mahasiswa tetapi tidak sesuai dengan hasil menggunakan Fuzzy Inference System.

Missed: Jumlah hasil yang tidak sesuai antara sistem menggunakan Fuzzy Inference System dengan pilihan utama (prioritas 1) mahasiswa.

Pada klasifikasi dengan jumlah keluaran kelas yang lebih dari dua (multiclass), cara menghitung recall dan precision dapat dilakukan dengan menghitung rata-rata dari nilai recall dan precision pada setiap kelas. Rumus yang digunakan untuk menghitung nilai recall dan precision sebagai berikut.

Recall $=\frac{\sum_{i=1}^{N} \text { Hits }}{\sum_{i=1}^{N}\left(\text { Hits }_{\text {Miss })}\right.} x 100 \%$

Precision $=\frac{\sum_{i=1}^{N} \text { Hits }}{\sum_{i=1}^{N}(\text { Hits }+ \text { Noise })} x 100 \%$

Tabel 3. Data hasil uji recall dan precision

\begin{tabular}{|c|c|c|c|}
\hline \multirow{2}{*}{ NO } & \multirow{2}{*}{$\begin{array}{c}\text { Konsentrasi } \\
\text { Jurusan }\end{array}$} & \multicolumn{2}{|c|}{ Nilai } \\
\cline { 3 - 4 } & & Recall & Precision \\
\hline 1 & $\begin{array}{c}\text { Sistem Tenaga } \\
\text { Listrik }\end{array}$ & $92,31 \%$ & $85,71 \%$ \\
\hline 2 & $\begin{array}{c}\text { Teknik } \\
\text { Komputer }\end{array}$ & $82,61 \%$ & $86,36 \%$ \\
\hline 3 & Elektronika & $81,25 \%$ & $61,9 \%$ \\
\hline 4 & Telekomunikasi & $58,33 \%$ & $87,5 \%$ \\
\hline
\end{tabular}

Nilai rata-rata recall pada penentuan konsentrasi mahasiswa menggunakan fuzzy inference system sebesar 78,625\%. Maka dapat diinterpretasikan bahwa recall Sistem Pengambilan Keputusan Pemilihan Konsentrasi Menggunakan Fuzzy Inference System termasuk dalam kategori tinggi.

Nilai rata-rata precision pada penentuan konsentrasi mahasiswa menggunakan fuzzy inference system sebesar $80,37 \%$. Maka dapat diinterpretasikan bahwa precision Sistem Pengambilan Keputusan Penjurusan Akademik Sekolah Menengah Atas Menggunakan Fuzzy Inference System termasuk dalam kategori tinggi.

\section{KESIMPULAN}

Sistem pendukung keputusan menggunakan logika fuzzy Mamdani bertingkat untuk menentukan bidang keahlian mahasiswa dapat mengefisiensikan tenaga dan waktu karena penentuan dilakukan secara instan pada 1 angkatan mahasiswa. Hasil logika fuzzy tahap pertama dianggap sebagai kelayakan dalam kemampuan dan hasil tersebut akan diproses kembali pada tahap kedua sebagai parameter masukan bersama dengan minat mahasiswa, keinginan orang tua dan keterampilan mahasiswa. Sehingga menghasilkan keputusan akhir berupa kelayakan terhadap bidang keahlian. Selanjutnya perbandingan tingkat akurasi penentuan bidang keahlian secara manual dan sistem fuzzy Mamdani secara bertingkat menggunakan 65 data mahasiswa sebesar $80 \%$. Adanya persentase error ini dipengaruhi oleh penyesuaian kapasitas bidang keahlian dan permintaan mahasiswa terhadap bidang keahlian tertentu. Pengukuran kualitas dari sistem menghasilkan $87.62 \%$ untuk kelayakan sistem dari total 21 responden.

\section{DAFTAR PUSTAKA}

[1]. Bova, S., Codara, P., MacCari, D., \& Marra, V. (2010). A logical analysis of Mamdani-type fuzzy inference, II. An experiment on the technical analysis of financial markets. 2010 IEEE World Congress on Computational Intelligence, WCCI 2010. https://doi.org/10.1109/FUZZY.2010.5584 834

[2]. Desi Vinsensia, Y. U. (2018). Penerapan Fuzzy Inference System (FIS) Metode Mamdani dalam Pemilihan Jurusan Perguruan Tinggi (STUDI KASUS: PELITA NUSANTARA MEDAN). 2(April 2018). 
[3]. Kusumadewi, S. H. (2006). Fuzzy MultiAttribute Decision Making (Fuzzy MADM). Graha Ilmu Yogyakarta.

[4]. Lahsasna, A., Ainon, R. N., \& Wah, T. Y. (2010). Enhancement of transparency and accuracy of credit scoring models through genetic fuzzy classifier. Maejo International Journal of Science and Technology.

[5]. Muslihudin, M. \& Oktafianto (2016). Analisis dan Perancangan Sistem Informasi Menggunakan Model Terstruktur dan UML. Yogyakarta: CV ANDI OFFSET.

[6]. Ramadan, P. R., Wiriasto, G. W., Iqbal, M. S., Elektro, J. T., Teknik, F., \& Mataram, U. (2018). Sekolah Menengah Atas Berdasarkan Kemampuan Akademik, Potensi Psikologi dan Minat Bakat Siswa menggunakan Fuzzy Inference System.

[7]. Ratama, N., \& Munawaroh. (2019). Perancangan Sistem Informasi Sosial Learning untuk Mendukung Pembangunan Kota Tangerang dalam Meningkatkan Smart city Berbasis Android. SATIN - Sains Dan Teknologi Informasi.

[8]. Ross, T. J. (2010). Fuzzy Logic with Engineering Applications: Third Edition. In Fuzzy Logic with Engineering Applications: Third Edition. https://doi.org/10.1002/9781119994374

[9]. Salman AbdulWahed, M., \& Seno Ismat, N. (2012). A Comparison of Mamdani and Sugeno Inference Systems for a Satellite Image Classification. Anbar Journal for Engineering Sciences.

[10]. Yulmaini, Y. (2015). Penggunaan Metode Fuzzy Inference System (Fis) Mamdani Dalam Pemilihan Peminatan Mahasiswa Untuk Tugas Akhir. Jurnal Informatika Darmajaya, 15(1), 10-23. 